\title{
A GIS TOOL FOR ANALYSIS AND INTERPRETATION OF COASTAL EROSION MODEL OUTPUTS (SCAPEGIS)
}

Koukoulas S. ${ }^{1}$, Nicholls R.J. ${ }^{2}$, Dickson M.E. ${ }^{3}$, Walkden M.J. ${ }^{4}$, Hall J.W. ${ }^{4}$, Pearson S.G. ${ }^{5}$, Mokrech, M. ${ }^{2}$ and Richards, J. ${ }^{2}$

${ }^{1}$ University of the Aegean, Geography Dept., University Hill, Mytilene 81100, Greece, skouk@geo.aegean.gr,

2 Southampton University, School of Civil Engineering and the Environment and the Tyndall Centre for Climate Change Research, Highfield, Southampton SO17 1BJ, UK, R.J.Nicholls@soton.ac.uk, M.Mokrech@soton.ac.uk,julie.richards@soton.ac.uk

3 NIWA (National Institute of Water and Atmospheric Research), Christchurch, New Zealand, m.dickson@niwa.co.nz

${ }^{4}$ Tyndall Centre for Climate Change Research, University of Newcastle upon Tyne NE1 7RU, UK.jim.hall@ncl.ac.uk, mike.walkden@ncl.ac.uk

${ }^{5}$ British Geological Survey, Keyworth, Nottingham, UK, spearson@bgs.ac.uk

\begin{abstract}
The SCAPE (Soft Cliff and Platform Erosion) model of cliff toe retreat, and a cliff-top recession model, have been linked with a new flexible GIS tool (SCAPEGIS) to provide visualisation and analytical capability for the model results. 45 model runs exploring different sealevel rise and wave climate scenarios and protection choices are available. Outputs are available in the form of maps, dynamic visualisation, and descriptive statistics of key parameters such as cliff toe and cliff top position. It also allows analysis with other datasets such as land use and building location for impact evaluation, and hence supports shoreline management and cliff-top land use planning. Some preliminary results and ideas for further development are presented.
\end{abstract}

\section{INTRODUCTION}

The likely magnitude of coastal erosion over the coming decades is of great concern to scientists, policymakers and the general public, especially with the expectation of 
an acceleration in sea-level rise (SLR). In the UK, fluvial and coastal flood risk is now reasonably well-defined at the national and regional scales (Hall et al., 2003; Evans et al., 2004). In contrast, broad-scale modelling of coastal morphological changes remains a major challenge (e.g. Capobianco et al., 1999), even though recent studies are addressing the phenomenon and its determinants in a more realistic manner (e.g., Burgess et al., 2002; Townend and Burgess, 2004), including European-Union-scale assessments (RIKZ et al., 2004). In the UK, we are fairly certain that present and future erosion risk is much smaller than flood risk (Evans et al., 2004), but more detailed analysis of risks and responses is hindered by the limited knowledge of the size and location of erosion hazard zones for different shoreline change and management scenarios. The Soft Cliff And Platform Erosion (SCAPE) model results described by Dickson et al. (2005a; 2005b) provide a detailed dataset for such analysis for North-East Norfolk.

SCAPE is a process-based model that determines the reshaping and retreat of shore profiles along the coast (Walkden \& Hall, 2005; Dickson et al., 2005a). Shore recession proceeds through cycles of beach lowering from longshore transport, shore profile erosion, cliff toe retreat and the release of beach sediments from the cliff and platform. Predictions of cliff top recession are generated by taking the SCAPE predictions of cliff toe recession and then sampling, from the relevant distributions, first an initial cliff angle and then a sufficiently long sequence of angles $\alpha_{f}$ and $\alpha_{s}$ (within a Cliff Behavioural Unit, the cliff can be expected to fail when it reaches a average angle $\alpha_{f}$ and will, after failure, adopt an angle $\alpha_{s}$ ). Large numbers of samples of these sequences of angles are used to generate a histogram of predicted cliff top locations at given numbers of years in the future (Hall et al. 2002).

The SCAPE and cliff-top models provide the inputs to a new Geographical Information Systems (GIS) tool (SCAPEGIS) which provides the framework of analysis in this study. The target audience is coastal policymakers and planners who would like to visualise erosion predictions and analyse their implications, including possible responses, by integrating with other spatial datasets (e.g., land use) for impact estimation and decision support. Using GIS technology to visualise coastal erosion predictions provides a powerful means to understand coastal changes and their impact in local and regional scales (Brown et al., 2004). This work is part of a bigger research effort by the Tyndall Centre for Climate Change Research (see also Brown et al., 2004; Dickson et al., 2005a; Hall et al., 2005; Jude et al., 2005), which is making an integrated assessment of coastal erosion and flood risk within coastal sub-cell $3 \mathrm{~b}$ (for strategic planning of responses to flood and erosion hazards, the coastline of England and Wales has been divided into 11 cells, which each contain a number of sub-cells (DEFRA, 2001; Cooper et al., 2002)), and contributing to the Regional Coastal Simulator (www.tyndall.ac.uk).

\section{STUDY AREA}

The area studied was the cliffed coast of Norfolk from Weybourne to Happispurgh (within subcell 3b) as shown in figure 1. This area has been retreating through the Holocene (last 10,000 years), with typical 'natural' recession rates of up to $1 \mathrm{~m} / \mathrm{yr}$ 
(Clayton, 1989). The cliffs are dominantly composed of easily-eroded till deposits up to $70 \mathrm{~m}$ high. Erosion releases large quantities of sediment, the sand and gravel sized fractions of which are carried to neighbouring beaches. Those to the south east, fronting the low-lying Norfolk Broads, protect the coastal lowlands from North Sea floods (Hall et al., 2005). In recent times, much of the coast has been highly modified by coast protection (Clayton, 1989; Dickson et al., 2005a), which delays erosion of cliff-top land, but reduces the supply of sediment to the beaches.

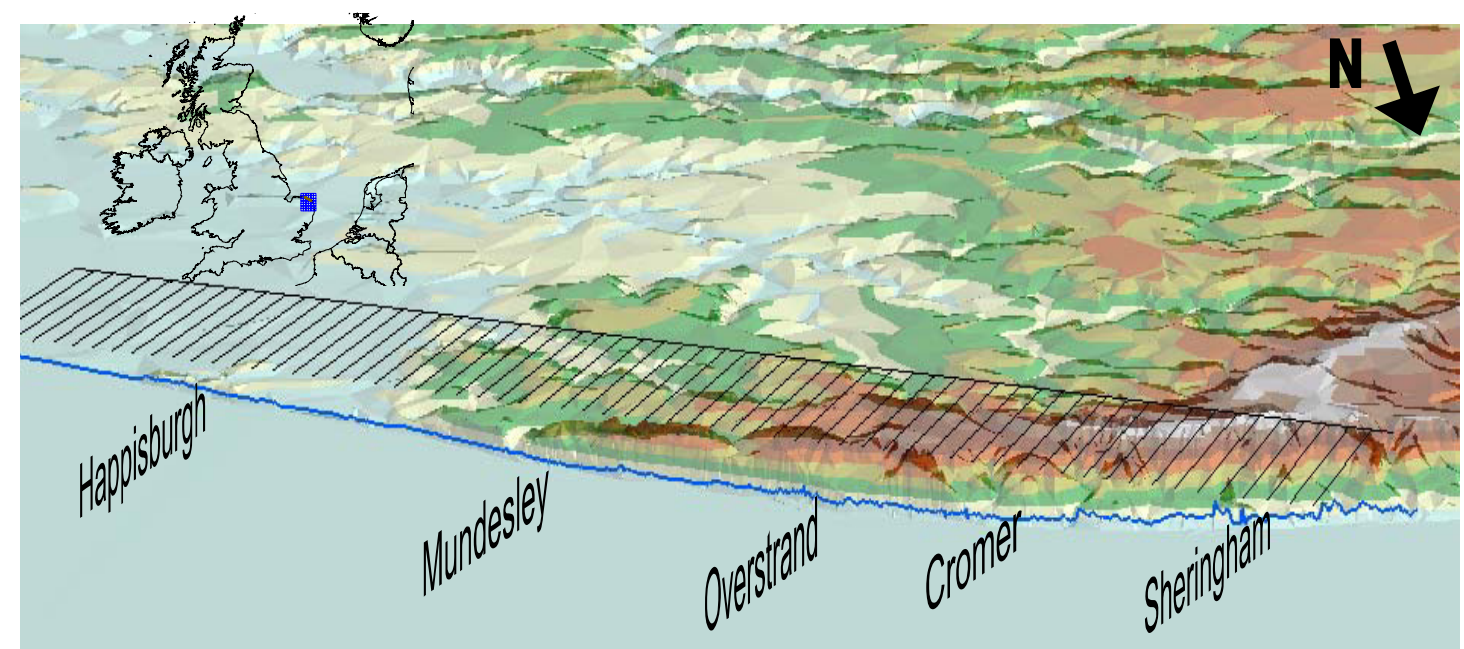

Fig. 1. Study area

\section{METHODOLOGY}

An "offline" protocol was used to link the SCAPE model and cliff top predictions with the GIS. This means that the model and the GIS tool can be operated separately. The advantage of this method is that it allows for independent development, use and updating of the two tools, although in the future, the SCAPE and cliff-top models could be embedded in the GIS if this was thought to be advantageous.

SCAPEGIS visualises data of past and future scenarios of shoreline evolution. The SCAPE model runs for a combination of 45 climate and management scenarios and the results produced (e.g. cliff toe position, beach volume) are input in the SCAPEGIS for visualisation, and input to the cliff top prediction model developed by Hall et al. (2002). The outputs of the cliff top prediction model are also input to SCAPEGIS together with other auxiliary data for visualisation and impact analysis.

The 45 scenarios used in the analysis are described in detail by Dickson et al. (2005a; 2005b). They comprise a range of sea-level rise scenarios (from 0.2 to $1.2-\mathrm{m}$ rise over the $21^{\text {st }}$ Century), wave scenarios (comprising no change, up to an increase in winter wave heights of $10 \%$, and changes in direction of $\pm 10^{\circ}$ as a sensitivity analysis), and a range of management scenarios (from no protection to total protection, with three more realistic intermediate protection options, comprising the existing situation (Management scenario 2), and two further options with a move to less protection by 2030). 
Table 1. Summary defining the $\mathbf{4 5}$ scenarios used in the analysis in terms of relative sea-level rise, wave conditions (indicated by $\mathrm{H}_{\mathrm{s}}$ low, etc.) and management approach.

\begin{tabular}{|c|c|c|c|c|c|c|c|c|c|}
\hline \multirow{3}{*}{$\begin{array}{l}\text { Management } \\
\text { Scenario } \\
\text { (\% of cliffed } \\
\text { coast } \\
\text { protected) }\end{array}$} & \multicolumn{9}{|c|}{ Relative sea-level rise scenario (2000 to 2100 ) } \\
\hline & \multicolumn{4}{|c|}{$\begin{array}{l}\text { Low } \\
\text { (0.2-m rise) }\end{array}$} & \multirow{2}{*}{ 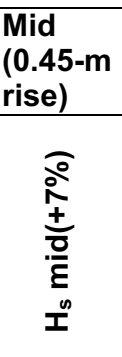 } & \multicolumn{4}{|c|}{$\begin{array}{l}\text { High } \\
\text { (1.2-m rise) }\end{array}$} \\
\hline & 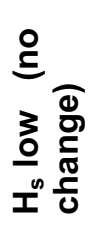 & $\begin{array}{l}\text { 응 } \\
\text { ㅇํㅇ } \\
\text { I }\end{array}$ & 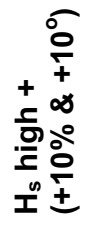 & 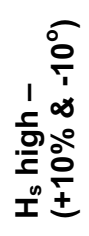 & & 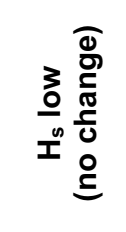 & 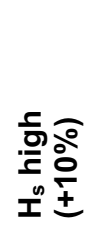 & 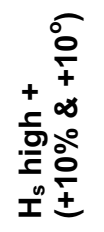 & 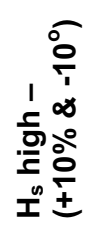 \\
\hline $1(100 \%)$ & 1 & 2 & 3 & 4 & 5 & 6 & 7 & 8 & 9 \\
\hline $2(71 \%)$ & 10 & 11 & 12 & 13 & 14 & 15 & 16 & 17 & 18 \\
\hline $3(34 \%)$ & 19 & 20 & 21 & 22 & 23 & 24 & 25 & 26 & 27 \\
\hline $4(16 \%)$ & 28 & 29 & 30 & 31 & 32 & 33 & 34 & 35 & 36 \\
\hline $5(0 \%)$ & 37 & 38 & 39 & 40 & 41 & 42 & 43 & 44 & 45 \\
\hline
\end{tabular}

\section{SCAPEGIS Description}

SCAPEGIS provides visualization and spatial analysis support to SCAPE and cliff top prediction models as described above, but other erosion models with a similar data output format could also be imported to SCAPEGIS. The main dialog of the current version of the user interface is shown in figure 2.

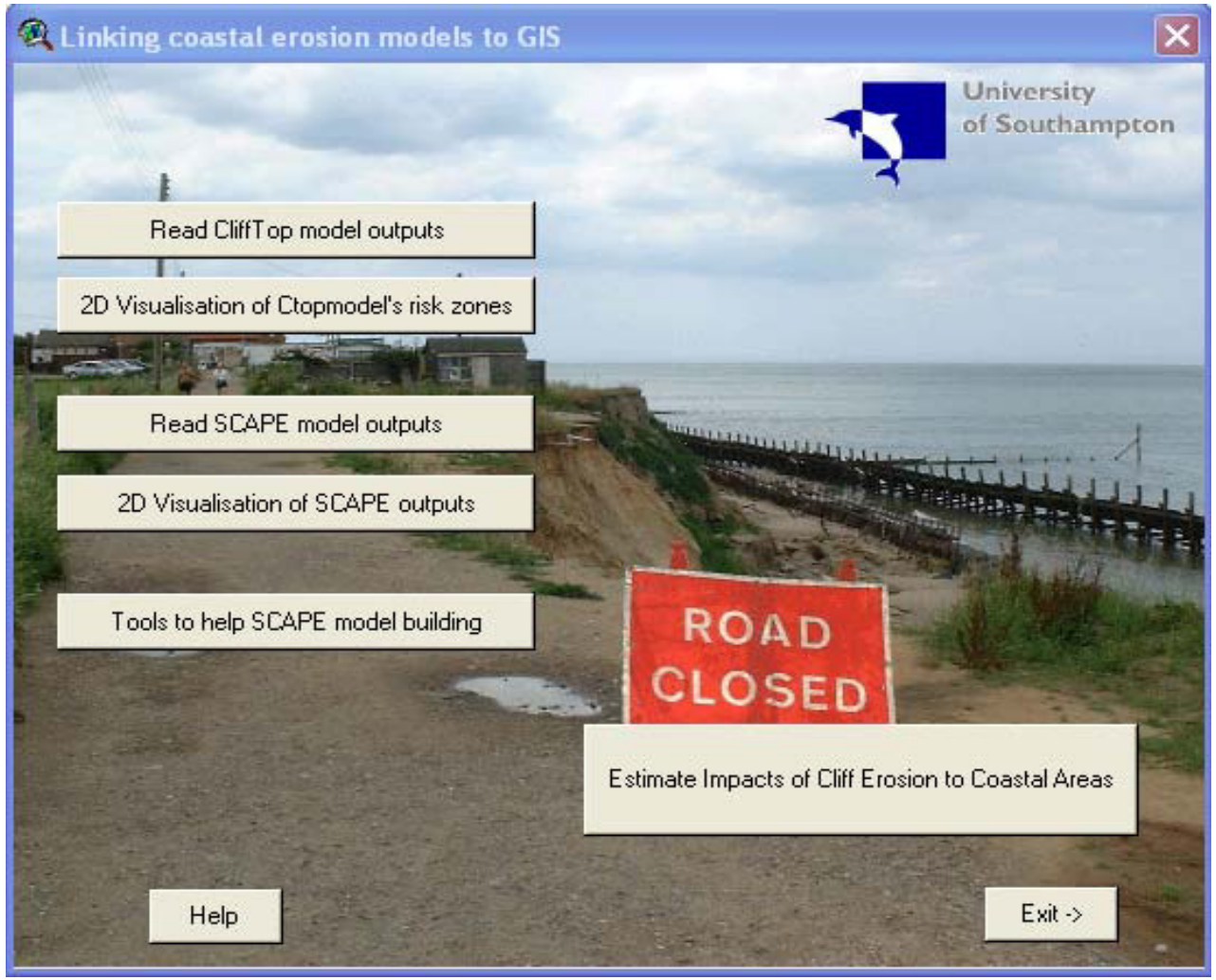

Fig. 2. The main dialog of SCAPEGIS 
Data input related to SCAPE results are possible using the third option (Read SCAPE model outputs), and data visualisation using the fourth option (2D Visualisation of SCAPE outputs) of the main form. An example of the modules available using the fourth option is shown in figure 3.

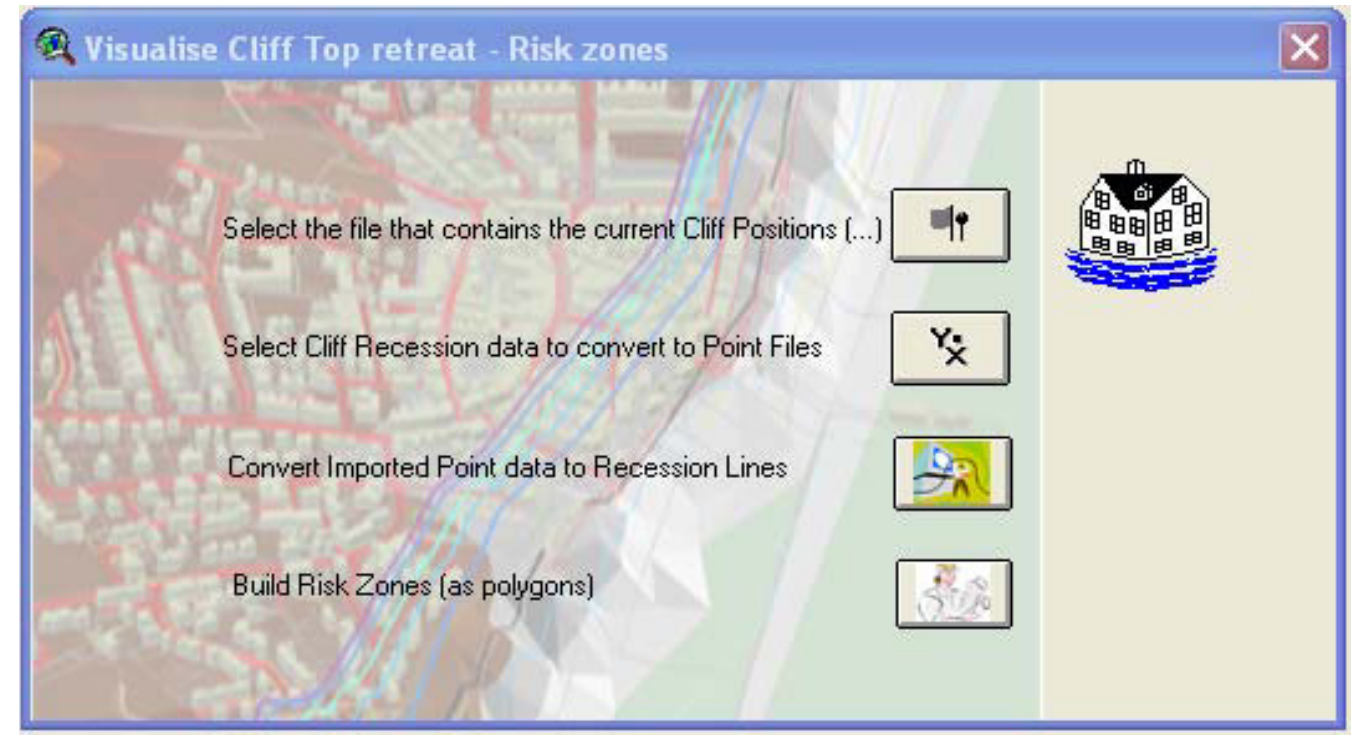

Fig. 3. The input and visualisation dialog of SCAPEGIS

The SCAPE simulations were conducted using a grid based on a series of 101 twodimensional ' $\mathrm{Y}$ ' sections spaced at $500 \mathrm{-m}$ intervals. Shore and beach profile evolution were calculated on the $\mathrm{Y}$ sections, whereas bulk longshore sediment transport is calculated halfway between each ' $\mathrm{Y}$ ' section (Dickson et al., 2005a). The major focus here is the cliffed section of the coast, comprising63 sections. Data provided from the SCAPE model includes:

1. Beach additions (yearly totals): The average amount of sediment added to the beach from platform and cliff erosion at each Y section each year (101 sections * 99 years (2001-2100)).

2. Beach volume (yearly average): The average volume of sediment along $500-\mathrm{m}$ sectors of coast held in beaches at each Y section each year (101 sections * 99 years (2001-2100)).

3. Recession distances: The total amount of cliff toe recession at each Y section each year (101 sections * 99 years (2001-2100)).

4. Longshore sediment flux moving past the southern and northern boundaries of the cliffed section (at Weybourne and a little south of Happisburgh, respectively) every tide. The annual net sediment flux can be calculated by adding the first 703 tides together (703 tides per year). 
5. The average relative level of the shore platform near the cliff toe for each $Y$ section every year.

Elements 1,2,3 and 5 are currently read into SCAPEGIS.

\section{Cliff Top model outputs}

SCAPE provides predictions of the cliff toe position, so to define cliff-top hazards these need to be translated to a cliff-top position. This was accomplished using the probabilistic cliff top model of Hall et al. (2002). This provides probability density functions (Pdf) of cliff top position for any cliff toe position. Recession distances (from initial cliff toe positions) corresponding to the $5^{\text {th }}$ and $95^{\text {th }}$ percentiles of the probability density function were extracted and used to generate the areas on the cliff top considered to be lost, at risk, and safe, given any cliff toe position from SCAPE (as shown in figure 4). The Pdf of cliff top positions accounts only for the uncertainty in the angle of the cliff slope and not for uncertainties in the locations of the cliff toe.

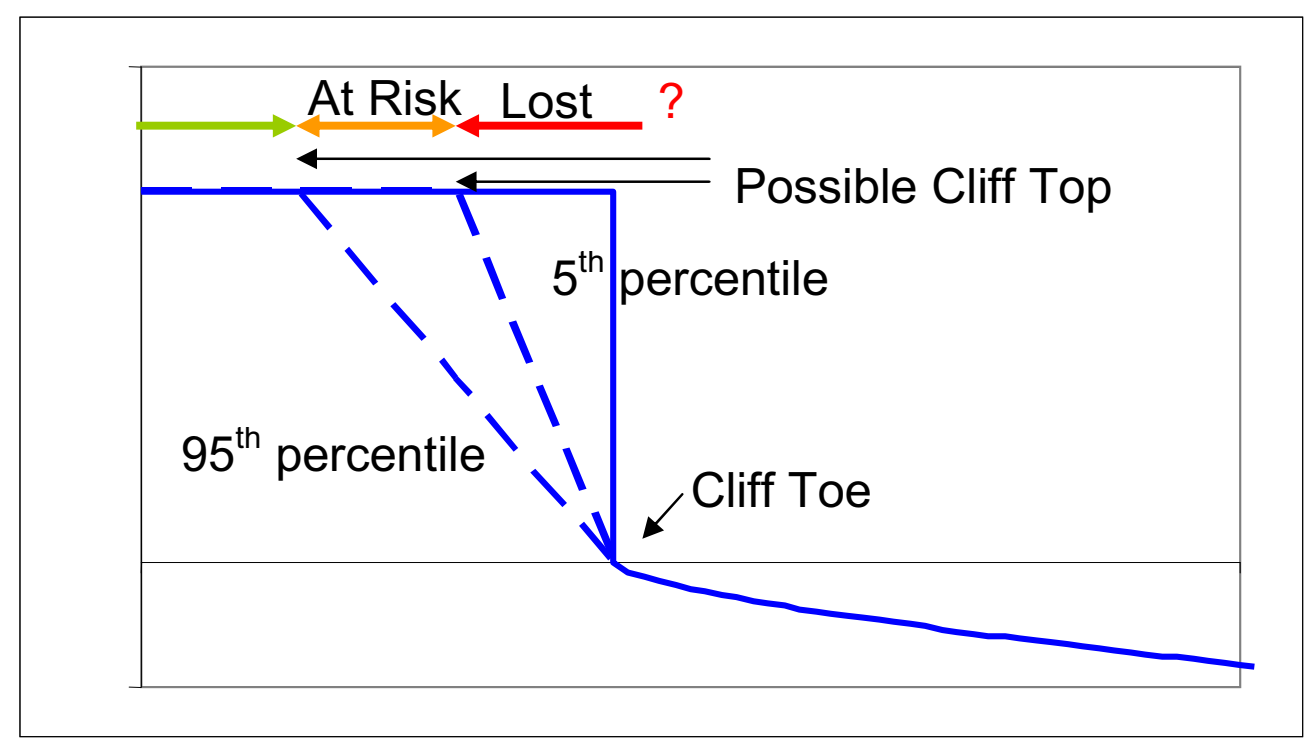

Fig. 4. Areas lost and at risk on the cliff-top. All other areas are considered safe

\section{Cliff Erosion Impacts}

Visualisation is a major element of SCAPEGIS, but the use of SCAPEGIS extents far beyond just producing maps. The tool developed has functions to link back to the SCAPE model, providing information to define the baseline and grid and for validation of the results, as well as other spatial information, in the form of coordinates, necessary for the model's operation. It should be noted that the parallel development of SCAPEGIS assisted the SCAPE model development. Most 
importantly, SCAPEGIS can be used to assess the impact of coastline changes on cliff top land use and associated urban areas, as well as changes in beach state.

The last option in the main dialog (figure 2) allows the user to estimate land losses due to simulated cliff erosion. If land use and infrastructure data or scenarios are available, then the types of land use and the number of infrastructure elements (e.g. buildings) that will be lost or at risk can be estimated.

The user of SCAPEGIS can build polygons for each model section to estimate land loss between the position in the "current" year and a predicted position (e.g. year 37, through 100). It is also possible to estimate land losses in specific areas (for example town boundaries) by selecting the appropriate sections. The form that allows impact estimation is shown in figure 5 .

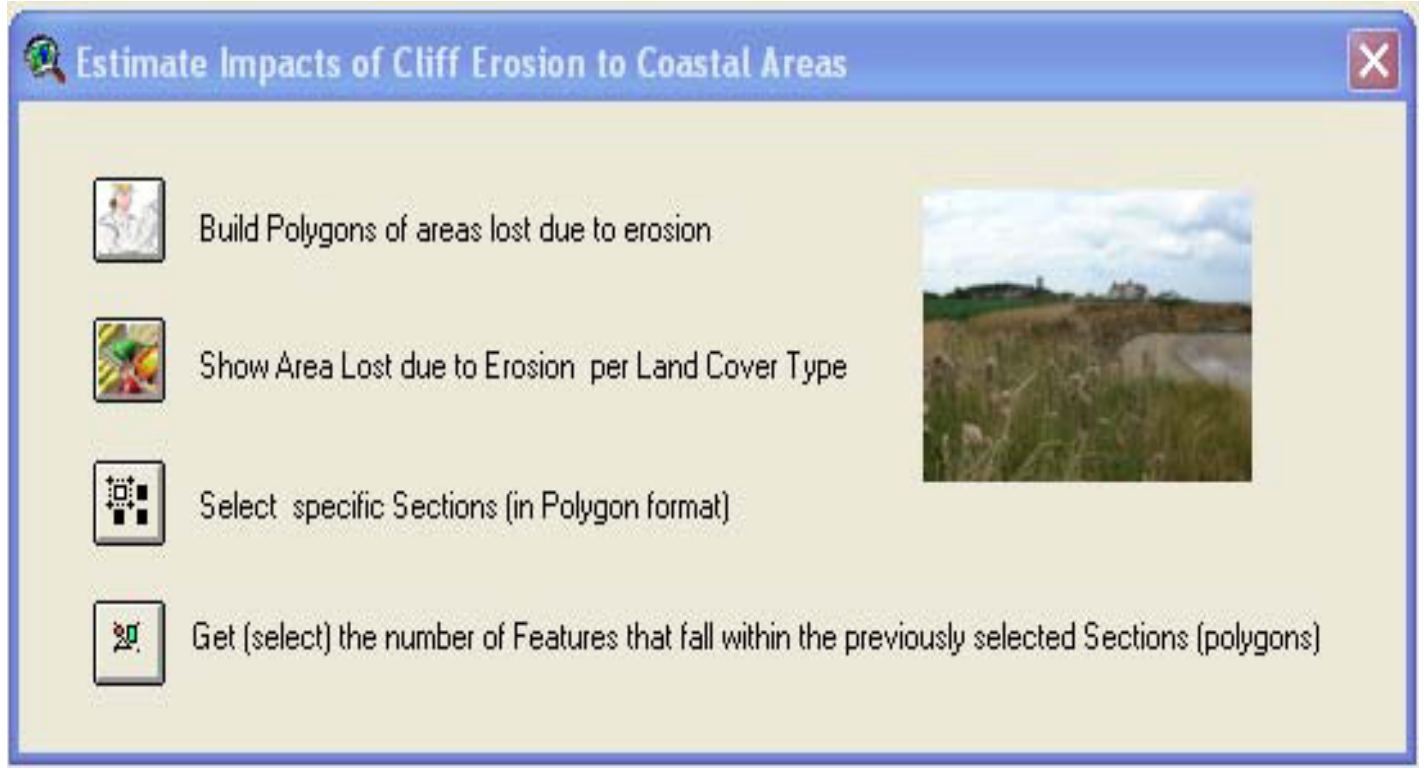

Fig. 5. The Impacts Estimation dialog of SCAPEGIS

Using auxiliary data, for the current study area, such as CORINE land cover maps, it was possible to estimate the type and the amount of land loss over the next 100 years under different management scenarios. Using OS Landline data as well as OS address layer it was possible to estimate the number of buildings and resident properties that will be lost or at risk in the next 100 years for each SCAPE scenario.

Preliminary economic analyses have also been made, in terms of both undiscounted losses, and the net present value of the losses as determined using the standard national project appraisal methods in England and Wales (Penning-Rowsell et al., 2003; Hall et al., 2000). The costs of residential properties was estimated based on the average value of (all) dwelling prices in 2001 (GBP 128184 in East England), while the value of arable land was considered to be $7300 \mathrm{GBP} / \mathrm{ha}$ (Penning-Rowsell et al., 2003). These preliminary estimates are being further investigated, including development of four scenarios of future cliff-top land use based on the Foresight 
socio-economic scenarios (cf. Evans et al., 2004) - giving potentially 180 different scenarios (4 x 45 scenarios).

\section{RESULTS \& DISCUSSION}

Visualisations of coastal recession and risk zone were performed for the area studied using different scenarios in order to assess the impact of protection strategies and climate change. The retreat of the cliff top (the risk zone) is shown below in figure 6 , for scenario 43 (remove all defences, high sea-level rise and $\mathrm{H}_{\mathrm{s}}$ high). Such images can be dramatic, especially in built areas, and are a useful way to communicate potential erosion risk (see also Jude et al., 2005).

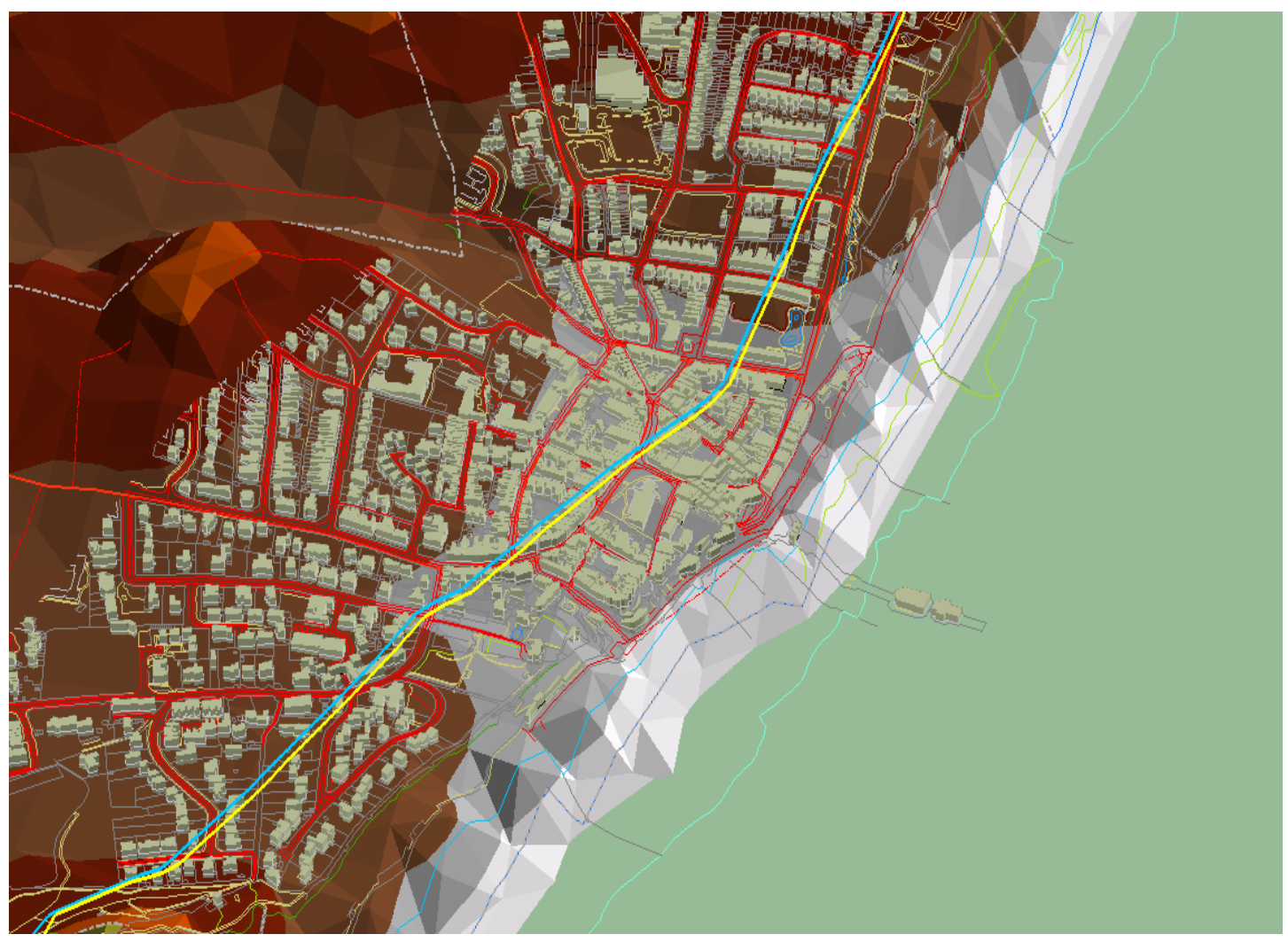

Fig. 6. An example of estimated cliff-top retreat for 2100 showing both recession lines (under scenario 43 - see Table 1). Land seaward of the right hand (yellow) line is assumed to be lost, while land between the two lines is at risk.

The loss of land, buildings and residential properties under the 45 scenarios has been calculated. While it is apparent that losses increase as the proportion of defended land decreases, it is also apparent that there are losses even when the entire coast is protected, especially land loss. This reflects an uncertainty in the baseline data compared to the SCAPE predictions, and also the linear representation of the coast between the 500-m ' $\mathrm{Y}$ ' cross-sections in SCAPEGIS. Given the small size of the erosion hazard zones, small errors in position translate into large possible errors in erosion risk. These problems are common when combining different geographic data 
and we are still investigating how best to deal with them. In the results shown here, losses are measured relative to the full protection option to minimise this effect: so losses are zero under the full protection option by definition. Hence, the results are meaningful in both absolute and particularly relative terms. Under the full protection option we also identify land and buildings that are at risk. However, this is correct, as there is potential for cliff failure, even if the cliff toe defences are maintained. An example is the cliff-top failure at Clifton Way in Overstrand, despite long-term clifftoe protection.

Figure 7 shows the building and residential property losses, while Figure 8 shows the total land and arable land losses, respectively. There are losses under all the cases without full protection, even with the low sea-level rise scenario. This stresses the erosional nature of this coast. Losses increase with sea-level rise and decreasing protection. Wave scenarios also influence the losses, but to a lesser degree than the other factors.

Land loss and residential property losses show different behaviour. Land loss increases dramatically as the amount of protection declines from $100 \%$ protection to $70 \%$ protection, but land losses do not grow so rapidly with further reductions in protection, although the losses are not necessarily occurring in the same locations. The difference in land losses between the low and high sea-level rise scenarios is about $20 \%$. Residential property losses increase as protection decreases, and this effect accelerates as protection falls to zero. The difference in residential property losses between the low and high sea-level rise scenarios is about $40 \%$. This difference in land and residential property losses mainly reflects the non-uniform distribution of residential properties. Hence, small additional land losses as defences are abandoned lead to significant additional residential property losses. This can be seen in figure 9, which shows the residential property losses per hectare of land loss as a function of protected length: unit losses of residential properties increase as the length of defences declines.

The undiscounted value of the residential properties lost is up to $£ 194$ million (in 2001 GBP). In terms of net present value, this is up to about $£ 1$ million/year. These values are incomplete as they do not include non-residential properties or transport link disruption. However, this omission is unlikely to change the overall picture that, while impressive when visualised (e.g. figure 6), the economic losses on the cliffed coast due to erosion are quite small under all the scenarios considered here. Hence, the erosion risk is much smaller than the flood risk that occurs to the south (Hall et al., 2005).

The results also show that if we protect the entire coast, or even maintain the present situation, the shore platform will continue to lower, and the beach volumes will continue to decline, resulting in declining beach width and area. This has implications in terms of increasing defence costs over time, and a degrading coastal environment, as the beach is an important element in the coastal aesthetic. 
Shoreline management planning in England and Wales is looking to develop more dynamic, less protected coasts (DEFRA, 2001; Cooper et al., 2002). As illustrated above, the underpinning models and results stored in SCAPEGIS provide an excellent basis to explore the implications of these important choices.

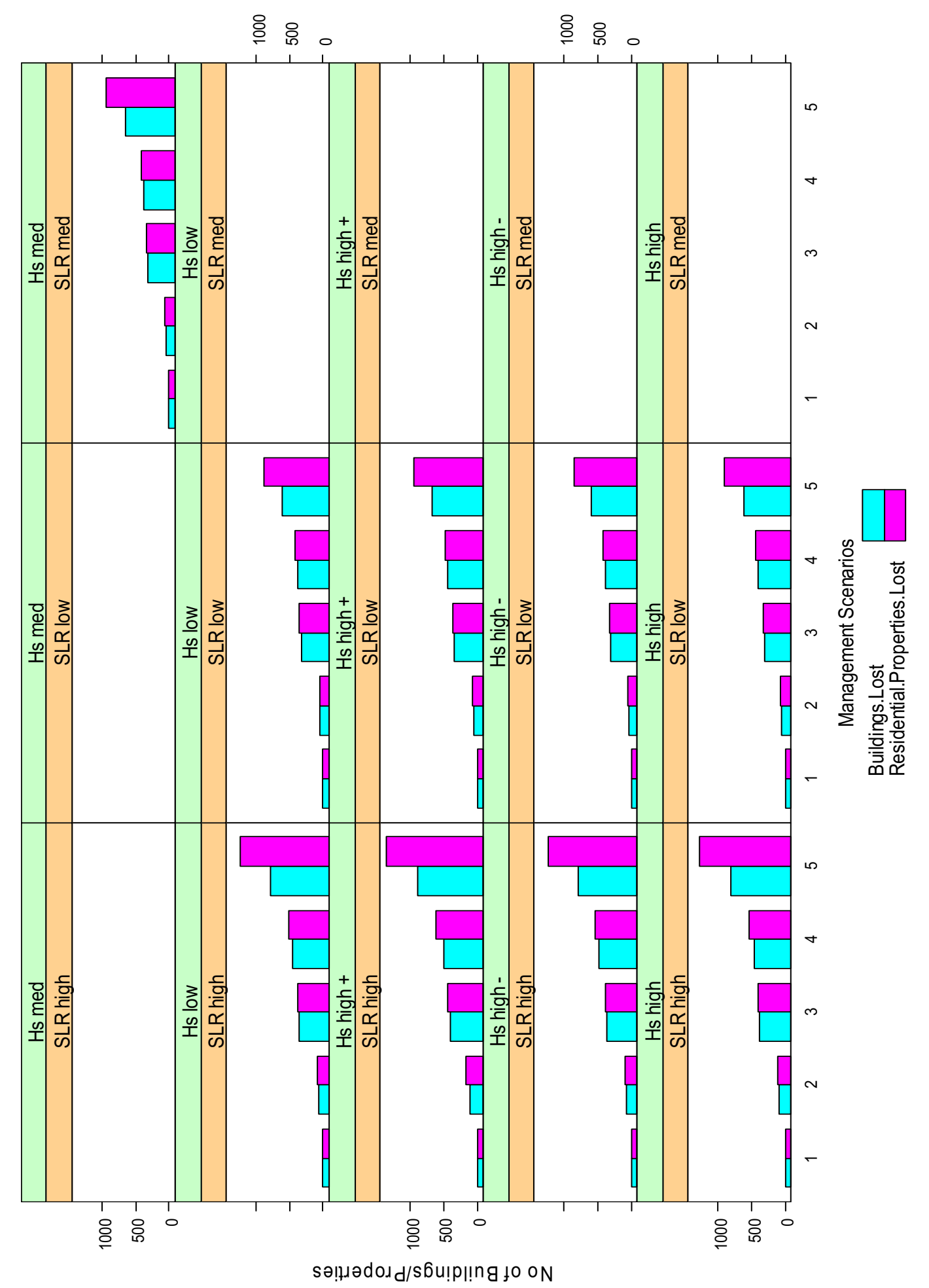

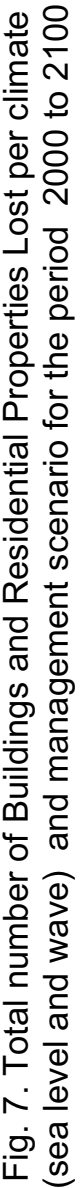


윰은응ㅇㅇㅇ

웃옫응ㅇㅇ

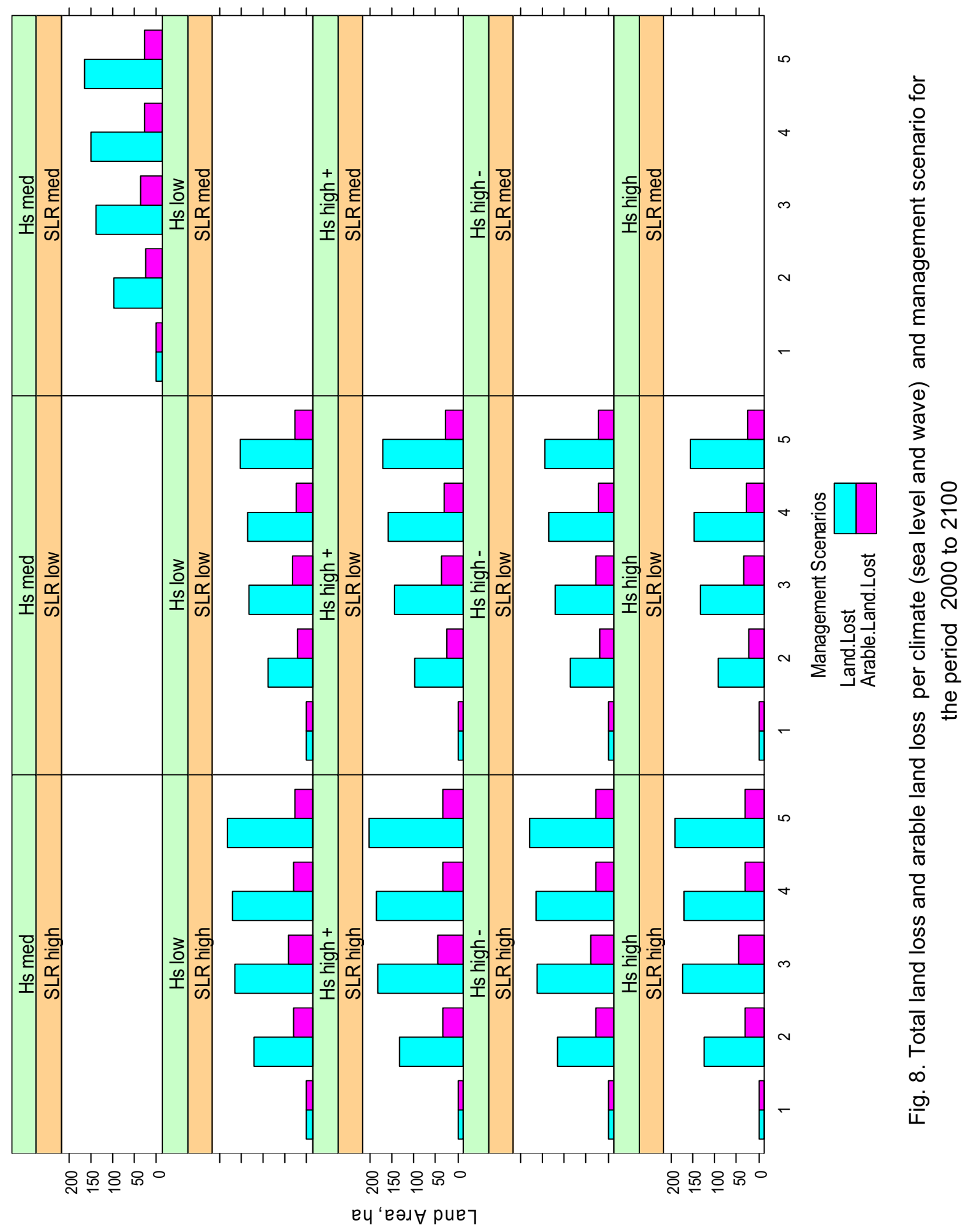




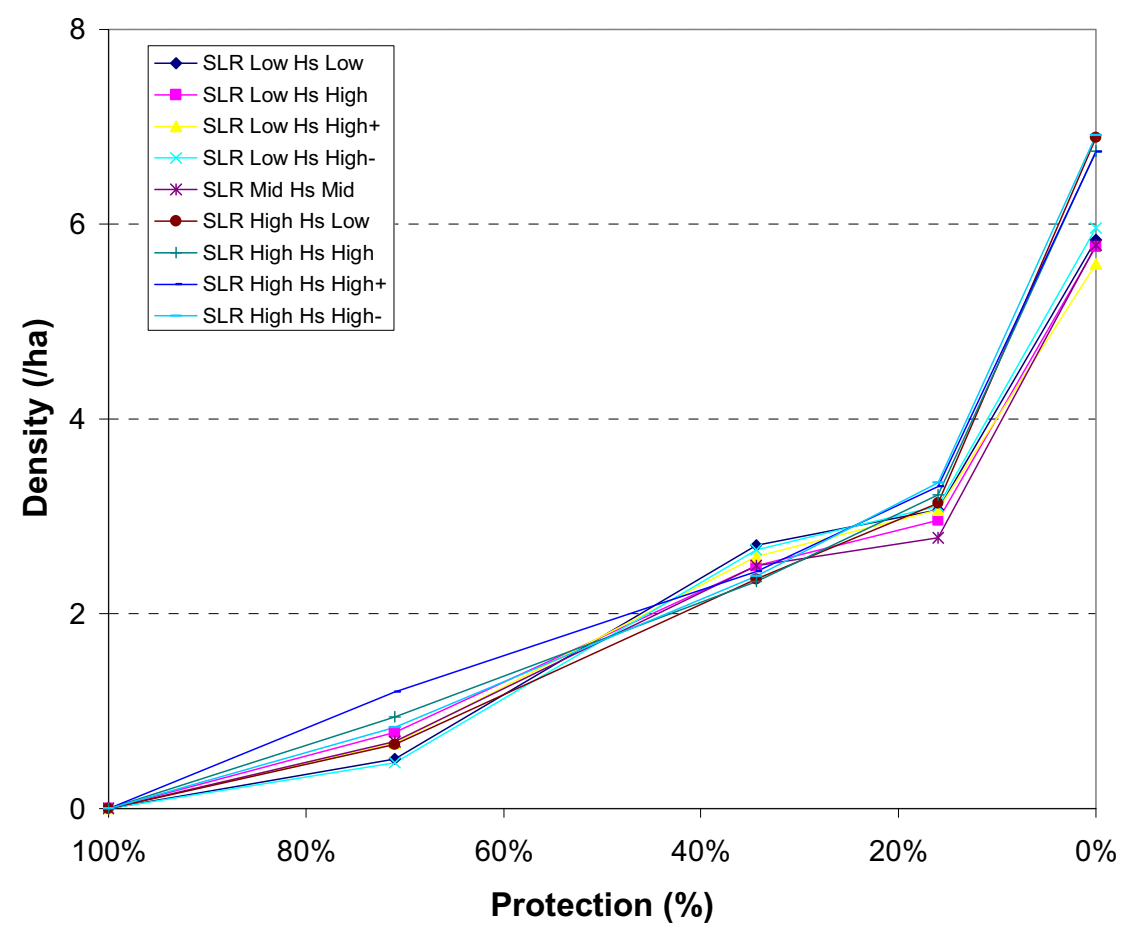

Fig 8. Residential property density on areas subject to land loss, versus the amount of protection. Results are shown for a range of climate scenarios.

\section{CONCLUSIONS \& FURTHER WORK}

The added value of a GIS tool such as SCAPEGIS to the analysis of the results of coastal erosion models has been demonstrated in this study. It was made possible to visualise cliff recession lines together with other layers representing the current situation, and to estimate the potential impacts of erosion under a wide range of climate and management scenarios. As further scenarios are developed, the SCAPEGIS data sets can be expanded. SCAPEGIS allows the constituent datasets to be analysed and hence explores the outcomes of different management approaches across a range of climate uncertainties.

Further analysis of costs and benefits of cliff retreat as well as linking the cliff-top changes with land use change models will be the next major step, as well as its link to flood risk (Hall et al., 2005). Given that there is widespread interest in shoreline management moving to a less protected, more dynamic coast we will also explore methods which could support planning for managed retreat on cliffed shorelines Lastly, the uncertainties of the model also need to be systematically explored. 


\section{ACKNOWLEDGEMENTS}

This research was funded by the Tyndall Centre for Climate Change Research. (Project T2.45 'An integrated coastal-sediment dynamics and shoreline response simulator')

\section{REFERENCES}

Brown I., S. Jude, S. Koukoulas, R. Nicholls, M. Dickson, M. Walkden, and A. Jones, 2004. Dynamic Simulation and Visualisation of Coastal Erosion: Past, Present and Future, GISRUK04, University of East Anglia, Norwich, 28-30 April 2004.

Burgess KA, Balson P, Dyer KR, Orford J, and Townend IH, 2002, Futurecoast - the integration of knowledge to assess future coastal evolution at a national scale, In: Proeceedings of 28th International Conference on Coastal Engineering, ASCE, New York, 3, pp. 3221-3233.

Capobianco M, de Vriend H, Nicholls R, Stive MJF, 1999, Coastal area impact and vulnerability assessment: the point of view of a morphodynamic modeller, Journal of Coastal Research, 15(3), 701-716.

Clayton, K. M. 1989. Sediment input from the Norfolk Cliffs, Eastern England - A century of coast protection and its effect. Journal of Coastal Research. 5, 433442.

Cooper, N.J., P.C. Barber, M.C. Bray and D.J. Carter. 2002: Shoreline management plans: a national review and an engineering perspective. Proceedings of the Institution of Civil Engineers, Water and Maritime Engineering, 154, 221-228.

DEFRA, 2001: Shoreline Management Plans: A Guide for Coastal Defence Authorities. Department for Environment, Food and Rural Affairs, London, UK.

Dickson, M. E., Walkden, M. J. A., Hall, J. W., Pearson, S. and Rees, J. 2005a. Numerical modeling of potential climate change impacts on rates of soft cliff recession, northeast Norfolk, UK. Proceedings of Coastal Dynamics, ASCE, New York, this volume.

Dickson, M. E., Walkden, M. J. A., Hall, J. W. 2005b. Potential impacts of climatic change on the rates of recession of soft rock shores and associated management implications, northeast Norfolk, UK. Climatic Change., in review.

Evans, E.P., Ashley, R., Hall, J.W., Penning-Rowsell, E.C., Saul, A., Sayers, P.B., Thorne, C.R., and Watkinson, A. 2004. Foresight Flood and Coastal Defence Project: Scientific Summary: Volume I, Future risks and their drivers. Office of Science and Technology, London, 366pp.

Hall, J.W., Dawson, R.J., Sayers, P.B., Rosu, C., Chatterton, J.B. and Deakin, R. A 2003. Methodology for national-scale flood risk assessment. Water and Maritime Engineering, ICE, 156(3): 235-247.

Hall, J.W., Dawson, R.J., Walkden, M. J. A., Dickson, M. E., Stansby P., Zhou J., Nicholls R., Brown I. and Watkinson A., 2005. Broad-scale analysis of morphological and climate impacts on coastal flood risk. Proceedings of Coastal Dynamics, ASCE, New York, this volume. 
Hall, J.W., Meadowcroft, I.C., Lee, E.M. and van Gelder, P.H.A.J.M. 2002. Stochastic simulation of episodic soft coastal cliff recession. Coastal Engineering, 46(3), 159-174.

Hall, J.W., Lee, E.M. and Meadowcroft, I.C. 2000. Risk-based benefit assessment of coastal cliff recession. Water and Maritime Engineering, ICE, 142, 127-139.

Jude, S.R., Brown, I., Koukoulas, S., Dickson, M., Walkden, M., Jones, A.P. and Watkinson, A. 2005. Exploring Future Coastlines - Initial Steps Towards the Development of an Integrated Coastal Simulation and Visualisation System. p.69-76. In Buhmann, E., Paar, P., Bishop, I.J. and Lange, E. (eds.) Trends in Real-Time Landscape Visualization and Participation. Herbert Wichmann Verlag. Heidelberg.361pp.

Penning-Rowsell, E.C., Johnson, C., Tunstall, S.M., Tapsell, S.M., Morris, J., Chatterton, J.B., Coker, A. and Green, C. 2003. The Benefits of Flood and Coastal Defence: Techniques and Data for 2003, Flood Hazard Research Centre, Middlesex University, London.

RIKZ, EUCC, IGN, UAB, BRGM, IFEN and EADS. 2004. Living with coastal erosion in Europe: Sediment and Space for Sustainability, Part 1: Major findings and Policy Recommendations of the EUROSION project.

Townend, I. and Burgess, K. 2004. Methodology For Assessing The Impact Of Climate Change Upon Coastal Defence Structures. In: Proceedings of 29th International Conference on Coastal Engineering, ASCE, New York, pp 39533966.

Walkden, M.J.A., and J.W. Hall 2005. A predictive Mesoscale model of the erosion and profile development of soft rock shores. Coastal Engineering 52, 535- 563. 